\title{
Cognition and drug adherence to oral hypoglycemic and antihypertensive agents in older adults [Corrigendum]
}

Bakouni H, Gentil L, Vasiliadis HM. Patient Prefer Adherence. 2019;13:891-899.

Following a review of the paper post-publication, the authors found that for the hypertension only and hypertension and diabetes mellitus groups, the estimates presented were for the absolute change and not the percentage change in Mini-Mental State Examination (MMSE) scores. This correction has no impact on the conclusions of the study. The authors had carried out analyses for both absolute and percentage change in MMSE scores. The authors apologize for this error.

In the Results section of the abstract, it should have read: "In participants with hypertension only, the change in MMSE scores was associated with adherence to antihypertensives ( $\beta$ 3.66; 95\% CI: 0.14-7.19). In participants with comorbid hypertension and diabetes mellitus type II, the change in MMSE scores was associated with adherence to both antihypertensive and oral hypoglycemic agents ( $\beta$ 2.78; 95\% CI: 0.10-5.46)."

In the Results section of the main paper, on page 896, in the second paragraph it should have read: "In the sample with hypertension, the change in cognitive status was positively associated with adherence to antihypertensive agents taken in the year prior to baseline interview ( $\beta$ 3.66; 95\% CI: 0.14-7.19)."

In the Results section of the main paper, on page 896 , in the third paragraph it should have read: "In the sample including participants diagnosed with both hypertension and diabetes mellitus type II, the change in MMSE scores was positively associated with adherence to both antihypertensive and oral hypoglycemic agents in the year following the baseline interview ( $\beta$ 2.78; 95\% CI: 0.10-5.46).”
The last 2 columns of Table 2 should have read as follows:

\begin{tabular}{|c|c|c|}
\hline & Hypertension & $\begin{array}{l}\text { Hypertension } \\
\text { and Type II } \\
\text { diabetes } \\
\text { mellitus }\end{array}$ \\
\hline & \multicolumn{2}{|c|}{$\begin{array}{l}\text { Unstandardized Beta estimates } \\
\text { and } 95 \% \mathrm{Cl}\end{array}$} \\
\hline Age & & \\
\hline$\geq 75$ vs $65-74$ years old & $-0.89(-1.84 ; 0.06)$ & $-0.86(-3.50 ; 1.78)$ \\
\hline Sex & & \\
\hline Female vs male & $0.20(-0.89 ; 1.29)$ & $-1.10(-3.96 ; 1.77)$ \\
\hline Marital status & & \\
\hline Married vs other & $-0.47(-1.44 ; 0.49)$ & $-0.95(-3.58 ; 1.67)$ \\
\hline Education level & & \\
\hline $\begin{array}{l}\text { Primary/secondary vs } \\
\text { Post-secondary/ } \\
\text { university }\end{array}$ & $-0.08(-1.16 ; 1.01)$ & $-0.13(-2.87 ; 2.61)$ \\
\hline $\begin{array}{l}\text { Common mental } \\
\text { diseases }\end{array}$ & & \\
\hline Yes vs No & $-1.08(-2.46 ; 0.29)$ & $0.37(-3.72 ; 4.46)$ \\
\hline $\begin{array}{l}\text { Charlson } \\
\text { Comorbidity Index }\end{array}$ & $-0.07(-0.42 ; 0.27)$ & $0.20(-0.84 ; 1.23)$ \\
\hline $\begin{array}{l}\text { Antidepressant/ben- } \\
\text { zodiazepine use }\end{array}$ & & \\
\hline Yes vs No & $-0.60(-2.17 ; 0.98)$ & $-2.5 \mathrm{I}(-7.74 ; 2.74)$ \\
\hline $\begin{array}{l}\text { Adherence in year } \\
\text { prior }\end{array}$ & $3.66(0.14 ; 7.19)^{*}$ & $-3.48(-7.23 ; 0.27)$ \\
\hline $\begin{array}{l}\text { Adherence in follow- } \\
\text { up period }\end{array}$ & 0.19 (-1.39; I.76) & $2.78(0.10 ; 5.46)^{*}$ \\
\hline
\end{tabular}

Note: Statistically significant at $P<5 \%$. 


\section{Publish your work in this journal}

Patient Preference and Adherence is an international, peer-reviewed, open access journal that focusing on the growing importance of patient preference and adherence throughout the therapeutic continuum. Patient satisfaction, acceptability, quality of life, compliance, persistence and their role in developing new therapeutic modalities and compounds to optimize clinical outcomes for existing disease states are major areas of interest for the journal. This journal has been accepted for indexing on PubMed Central. The manuscript management system is completely online and includes a very quick and fair peer-review system, which is all easy to use. Visit http:// www.dovepress.com/testimonials.php to read real quotes from published authors. 